Jurnal Gamaliel : Teologi Praktika

Vol 1, No 1, Maret 2019

\title{
KONSELING STRES BAGI PENGASUH ANAK BALITA
}

\author{
Oleh: \\ ${ }^{* 1}$ Efi Nurwindayani dan ${ }^{* 2}$ Eva Nurwiyati \\ ${ }^{* 1}$ Dosen Tetap STT Gamaliel \\ ${ }^{* 2}$ Dosen Tetap STT Gamaliel
}

Email: ${ }^{* 1}$ efinurwindayani@stt-gamaliel.ac.id, ${ }^{* 2}$ evanurwiyati@stt-gamaliel.ac.id

\begin{abstract}
ABSTRAK - Penelitian ini berjudul: Konseling Stres Pada Pengasuh Anak Balita. Tujuan penelitian ini adalah untuk menjelaskan cara mengatasi stres pada pengasuh anak balita. Model penelitian adalah kualitatif. Penelitian kualitatif dapat didesain untuk memberikan sumbangan terhadap teori, praktis, kebijakan, masalah-masalah sosial dan tindakan. Pengumpulan data diambil dari literatur, yaitu buku-buku dan informasi yang jelas sumbernya untuk dianalisa dan wawancara dengan beberapa pengasuh anak baliita. Hasil penelitian adalah langkah-langkah mengatasi stres secara teologis dan praktis sehingga menolong setiap pengasuh anak dalam mengatasi stres yang dialaminya.
\end{abstract}

Kata Kunci: Konseling, Stres, Pengasuh Anak Balita

\begin{abstract}
This study is entitled: Stress Counseling in Toddler Caregivers. The purpose of this study was to explain how to deal with stress in caregivers of toddlers. The research model is qualitative. Qualitative research can be designed to contribute to theory, practice, policy, social problems and actions. Data collection is taken from the literature, namely books and information that is clearly the source for analysis. The results of the study are steps to deal with stress theologically and practically so that it helps each child caregiver in dealing with the stress they experience
\end{abstract}

Keywords: Counseling, Stress, Toddler Caregivers

\section{Latar Belakang Masalah}

Merawat anak balita bukanlah pekerjaan yang mudah. Anak balita sedang dalam fase tumbuh kembang. ${ }^{1}$ Mereka

\footnotetext{
${ }^{1}$ Pertumbuhan berkaitan dengan masalah perubahan dalam besar, jumlah, ukuran yang bisa diukur dengan
}

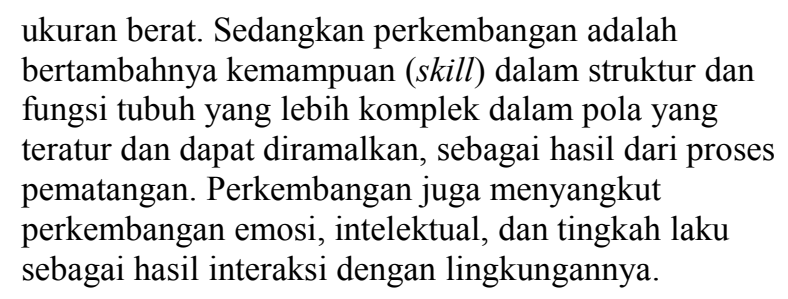

ukuran berat. Sedangkan perkembangan adalah bertambahnya kemampuan (skill) dalam struktur dan fungsi tubuh yang lebih komplek dalam pola yang teratur dan dapat diramalkan, sebagai hasil dari proses pematangan. Perkembangan juga menyangkut perkembangan emosi, intelektual, dan tingkah laku sebagai hasil interaksi dengan lingkungannya. 
membutuhkan pendampingan dan perawatan intensif. Kehadiran pengasuh anak balita (orang tua anak, pengasuh di tempat penitipan anak, asisten rumah tangga dan kerabat terdekat) sangat dibutuhkan untuk menolong tumbuh kembangnya.

Berbagai aktifitas pengasuh anak balita dilakukan dalam beberapa hal, diantaranya: pertama, perawatan fisik seperti memandikan, memberi makan dan minum yang bergizi, menidurkan dan lain-lain. Kedua, perawatan psikologis seperti mene-nangkan saat anak balita rewel atau mengalami ketakutan. Ketiga, mendampingi saat melakukan aktifitas motorik seperti berjalan, berlari, bermain dan lain-lainnya.

Aktifitas pengasuhan anak balita membutuhkan kekuatan ekstra bagi para pengasuhnya. Anak balita tidak selalu dapat diasuh dengan mudah. Beberapa pekerjaan dalam pengasuhan berpotensi menimbulkan stres bagi pengasuhnya. Berbagai pernyataan seperti "mengurusi anak ini membuat saya lelah", "susah banget mengurus anak ini", "saya tidak tahu harus berbuat apalagi untuk anak ini", "sepertinya apa yang saya lakukan untuk anak ini tidak membawa hasil" merupakan bentuk-bentuk keluhan yang sering dikemukakan oleh para pengasuh anak. Keluhan-keluhan tersebut menunjukkan bahwa pengasuh anak mengalami situasi yang menekan (stres). ${ }^{2}$

Banyak faktor penyebab stres. Salah satunya diceritakan oleh seorang pengasuh anak balita dalam sebuah tempat penitipan

(Soetjiningnsih, Tumbuh Kembang Anak, Penerbit Buku Kedokteran, EGC, Jakarta, 1995).

${ }^{2}$ Monty P Satiadarma, Mewaspadai Stres Pengasuh. 295-296 anak dengan mengatakan: "saya pernah mengalami stres dalam mengasuh anak di sini. Kelelahan menjadi faktor yang memicu stres. Selain itu, kadang belum menemukan langkah dan cara yang tepat untuk menghadapi anak dengan keunikkan masing-masing. Ada orangtua yang tidak dapat diajak bekerja sama, itu menambah beban kerja saya."3

Stres pada pengasuh anak membawa dampak bagi anak maupun pengasuh. Seorang ibu yang memiliki dua anak balita dan juga menjadi staf di sebuah kantor swasta menceritakan pengalaman stresnya dan dampaknya dengan mengatakan: "Saya stres di saat anak rewel, tidak mau makan, padahal segala usaha sudah saya lakukan. Pikiran saya jadi kacau, tidak damai sejahtera, salah komunikasi dengan suami dan anak semakin rewel."

Stres yang dialami pengasuh anak balita perlu diatasi. Karena itu, penulis tertarik untuk membuat penelitian tentang konseling stres pada pengasuh anak balita. Tujuannya penelitian ini adalah menemukan langkahlangkah mengatasi stres bagi pengasuh anak balita.

\section{Metodologi Penelitian}

Penelitian ini menggunakan metode penelitian kualitatif. Penelitian kualitatif adalah penelitian yang menekankan pada quality atau hal yang terpenting dari sifat suatu barang/ jasa. Penelitian kualitatif dapat didesain untuk memberikan sumbangan terhadap teori, praktis, kebijakan, masalahmasalah sosial dan tindakan.

Pengumpulan data diambil dari literatur, yaitu buku-buku dan informasi yang jelas

\footnotetext{
${ }^{3}$ Wawancara dengan seorang ibu rumah tangga
} 
sumbernya untuk dianalisa. Bahan penelitian yang telah dikumpulkan kemudian dipilahpilah berdasarkan tujuan penelitian, kemudian dianalisa dan disusun menjadi laporan hasil penelitian. Untuk memudahkan penyimpanan dan pencarian kembali, bahan diberi nama (file) sesuai dengan informasi yang tercakup di dalamnya. ${ }^{4}$

\section{HASIL PENELITIAN}

\section{A. Pengasuh Anak Balita}

Anak balita adalah anak yang berusia di bawah lima tahun. Periode ini merupakan masa penting dalam tumbuh kembang anak karena pada masa ini akan mempengaruhi dan menentukan perkembangan anak selanjutnya.

Dokter Soetjiningsih dalam bukunya yang berjudul Tumbuh Kembang Anak mengatakan: pada masa balita, anak mengalami perkembangan dalam kemampuan berbahasa, kreativitas, kesadaran sosial, emosional dan intelegensianya. Perkembangan moral serta dasar-dasar kepribadian juga dibentuk pada masa ini.

Terdapat beberapa parameter yang dapat dipakai untuk menilai perkembangan anak balita yaitu: pertama, personal social yaitu aspek yang berhubungan dengan kemampuan mandiri, bersosialisasi dan berinteraksi dengan lingkungannya. Kedua, fine motor adaptive (gerakan motoric halus) yaitu berhubungan dengan kemampuan anak mengamati sesuatu dan melakukan gerakan. Ketiga, language yaitu kemampuan member-

\footnotetext{
${ }^{4}$ Mudrajad Kuncoro, Metode Riset untuk Bisnis \& Ekonomi: Bagaimana Meneliti \& Menulis Tesis., 124.
}

kan respon terhadap suara, mengikuti perintah dan bicara spontan. ${ }^{5}$

Anak dalam periode ini membutuhkan kehadiran seorang pengasuh anak. Pengasuh anak menunjuk pada orang-orang yang bertugas mengasuh anak baik orang tua anak, pengasuh di tempat penitipan anak, asisten rumah tangga dan kerabat terdekat. Kegiatan mengasuh anak secara umum bertujuan untuk: pertama, memberikan landasan kehidupan keluarga pada anak-anak. Kedua, mempersiapkan anak mampu beradaptasi dalam menyiasati kehidupan di masa yang akan datang. Ketiga, menanamkan sikap disiplin pada anak. Keempat, membangun rasa percaya diri pada anak. ${ }^{6}$

Seorang pengasuh anak balita harus memiliki kemampuan-kemampuan tertentu dalam mengerjakan tugas pengasuhan. Kemampuan tersebut diantaranya pertama, menguasai ketrampilan sederhana seperti: memberi makan, menolong berpakaian, toilet training dan mengajak bermain. Kedua, menolong balita mengenal dirinya, dan memiliki kesadaran diri sebagai sumber tindakan, ide, kata-kata, dan perasaan, dan mulai evaluasi diri yang reflektif. Ketiga, mengatur kecerdasan emosi anak. Seperti kemampuan menunggu, kenyamanan diri, menahan godaan, mengikuti aturan dan arahan. Keempat, menolong balita memiliki empati, moralitas dan standar dalam relasi dengan sosialnya. Kelima, menolong memahami identitas gender dan identifikasi peran gender

\footnotetext{
${ }^{5}$ Soetjiningnsih, Tumbuh Kembang Anak, Penerbit Buku Kedokteran, EGC, Jakarta, 1995 297.
} 
yang mereka miliki. Keenam, menolong balita terhubung dengan orang lain dan anggota masyarakat sehingga mampu bermain dan bersosialisasi. $^{7}$

\section{B. Stres Pengasuh Anak Balita}

Menurut hasil penelitian, ada 30 pekerjaan yang paling banyak menimbulkan stres, salah satunya adalah seorang perawat. ${ }^{8}$ Pengasuh anak balita termasuk dalam kategori pekerjaan sebagai perawat karena tugas mereka sebagai perawat anak-anak dengan usia dibawah lima tahun.

Hans Selye penulis buku Stress Without Distress memberikan definisi stres adalah tanggapan yang menyeluruh dari tubuh terhadap setiap tuntutan yang datang atasnya. ${ }^{9}$ Seorang yang mengalami stres akan nampak dari gejala-gejala yang dialaminya. Gary R. Collins menyebutkan ada gejala fisik, mental dan rohani. Secara fisik seorang yang stress mengalami kelelahan tubuh. Hal ini disebabkan oleh keadaan tubuh yang menanggung beban tambahan dan kemampuannya untuk melawan penyakit menjadi sangat berkurang. Secara mental, seorang yang mengalami stres cenderung menjadi pelupa, kurang sabar, tidak efisien, bertele-tele, mudah tersinggung dan tidak dapat kerja lama dengan orang lain. Secara rohani, seorang

${ }^{7}$ parenting-2nd-vol-1-children-and-parenting.pdf

${ }^{8}$ Keith W. Sehnert, M.D., Mengendalikan Stres Dalam Rumah Tangga Dan Pekerjaan, 33

${ }_{9}^{9}$ Agus M. Hardjana, Stres Tanpa Distres. Seni Mengolah Stres, 23 yang stres dapat menghambat pertumbuhan rohaninya. ${ }^{10}$

Stres di pekerjaan dapat disebabkan oleh beberapa faktor seperti: tidak memiliki kualifikasi untuk suatu pekerjaan, terlalu banyak tanggung jawab atau sebaliknya, merasa bosan, tidak mampu beradaptasi dengan perubahan dalam rutinitas pekerjaan. ${ }^{11}$

Secara khusus, stres pada pengasuh anak balita disebabkan oleh beberapa faktor. Pertama, kondisi anak. Anak dengan kondisi yang "susah" diasuh menjadikan pengasuh mudah terkena stres. Seperti yang disaksikan seorang pengasuh anak "anak ini perlu penanganan khusus. Susah dikendalikan. Saya sampai stress". Kedua, kelelahan. Pekerjaan pengasuhan yang memakan banyak waktu dapat menyebabkan pengasuh anak mengalami kelelahan. Kelelahan ini memicu timbulnya stres. Seperti yang dijelaskan oleh seorang ibu muda "saya seorang istri yang secara penuh waktu mengurus anak saya yang masih kecil". Saya jujur saat kelelahan karena mengurus anak, saya menjadi stress. Perasaan tertekan dan ingin marah saya alami." 12 Ketiga, kurangnya ketrampilan dalam pengasuhan anak, khususnya jika anak dalam kondisi berkebutuhan khusus. Keempat, faktor kepribadian. Kepribadian tipe A cenderung mudah terkena stres. Salah satu ciri kepribadi tipe A adalah tidak sabar dengan penundaan atau penyelaan. ${ }^{13}$ Seorang anak balita kadang 90

${ }^{10}$ Gary R. Collins, Konseling Kristen Yang Efektif,

\footnotetext{
${ }^{11}$ Andres Goliszek, Manajemen Stres, 53

${ }^{12}$ Wawancara dengan seorang ibu muda

${ }^{13}$ Keith W. Sehnert, M.D., 39
} 
lamban dalam melakukan perintah. Misalnya diminta segera tidur atau makan, tetapi malah melakukan yang sebaliknya. Hal ini membuat pengasuh anak mudah terkena stres.

Stres berpengaruh bagi kehidupan seseorang, pertama pada pikiran yaitu mengganggu kerja pikiran dan menyulitkan konsentrasinya. Kedua, emosi yaitu perasaaan takut, sedih dan marah. Ketiga, perilaku yang konstruktif (membangun) atau destruktif (merusak). ${ }^{14}$ Secara khusus bagi pengasuh anak balita, stres mempengaruhi perilaku pengasuhan terhadap anak-anak yang diasuhnya.

Pengasuh cenderung bertindak reaktif dalam mengasuh karena persepsi atas ketidakberdayaan mereka sendiri. Bentuk tindakan reaktif pengasuh sangat beragam dan tingkat pendidikan pengasuh memiliki pengaruh yang sangat bermakna bagi mereka dalam memberikan respon pengasuh kepada anak. Jika stres tidak ditangani dengan baik maka akan mengakibatkan penyakit karena menurunnya daya tahan tubuh seseorang. Penyakit yang disebabkan stres adalah penyakit psikosomatis antara lain bisul, radang perut, asma, kepala pusing yang kronis, eksim, penyakit kulit, tekanan darah tinggi, penyakit jantung dan kanker. ${ }^{15}$

\section{Konseling Stres Pada Pengasuh Anak Balita}

Seorang pengasuh anak balita yang mengalami stres membutuhkan konseling untuk mengatasi stres tersebut. Konseling adalah hubungan timbal balik antara dua individu, yaitu konselor yang berusaha menolong atau membimbing dan konseli yang

\footnotetext{
${ }^{14}$ Ibid, 7

${ }^{15}$ Ibid, 10
}

membutuhkan pengertian untuk mengatasi persoalan yang dihadapinya.

Seorang konselor Kristen akan berusaha mengaplikasikan kebenaran Firman Tuhan atas persoalan-persoalan hidup ini. Melalui langkah-langkah selama proses konseling diharapkan dapat mengubah sikap atau tingkah laku yang merugikan konseli dan menolongnya mengerti nilai-nilai kehidupan yang ada. Selain itu juga menolong konseli mengerti sebab-sebab dari persoalan yang timbul dan menyadari akan dosanya, mengakui di hadapan Tuhan dan memulai suatu kehidupan yang baru. ${ }^{16}$

Terdapat empat fase (langkah) dalam proses konseling: pertama, fase pendahuluan. Pada fase ini ada tujuan yang akan dicapai yaitu: bertemu dengan pengasuh anak balita yang sedang mengalami stress, membangun hubungan baik dengan orang tersebut dan menjelaskan persoalan yang sedang dihadapinya. Kedua, fase penetapan tujuan. Tujuan yang ditetapkan harus spesifik dan mampu untuk dilaksanakan. Bagi pengasuh anak balita yang sedang mengalami stres maka tujuan konseling adalah menemukan faktor penyebab stres dan mengatasi dengan cara yang benar. Ketiga, fase mengerjakan penyelesaian. Konselor akan mendorong konseli untuk melakukan langkah praktis dan realistis dalam menyelesaikan masalahnya. Sebagai contoh, seorang pengasuh anak balita yang stres karena kondisi anak yang susah untuk diasuh, maka pengasuh akan mengambil waktu untuk berdoa dan berpuasa. Bukan hanya untuk anak tersebut tetapi juga untuk diri sendiri agar dapat lebih sabar dan tekun dalam mengasuh dan merawatnya. Apabila fase ini gagal dilaksanakan oleh

\footnotetext{
${ }^{16}$ Gary R. Collins, Konseling Kristen Yang Efektif, (Malang: SAAT, 2012), 13-14
} 
konseli maka perlu dievaluasi dan dicoba lagi. Fase terakhir adalah fase terminasi akhir. Fase ini adalah fase dimana konselor dan konseli sudah mengerti persoalannya, membicarakan dengan rinci, mencapai beberapa tujuan dan mulai dapat mengatasi. Pada fase inilah proses konseling dapat diakhiri. ${ }^{17}$

Secara praktis, Gary R. Collins memberikan penjelasan tentang beberapa cara menolong konseli yang mengalami stress. Pertama, rileks. Jika ada tekanan datang, biasanya jantung akan berdenyut lebih cepat oleh sebab itu tubuh menjadi tegang dan dalam keadaan ini sangat sulit bagi seseorang untuk berpikir bagaimana mengatasi stres. Akan sangat menolong jika tubuh yang stres dapat menjadi rileks. Secara praktis, menjadikan tubuh rileks dapat dilakukan dengan beberapa cara seperti mendengarkan musik yang lembut, mandi air hangat, membayangkan sesuatu yang indah dan merenungkan ayat-ayat Firman Tuhan.

Kedua, menolong konseli menemukan penyebab stress dan cara mengatasinya. Ketiga, mencoba mengenali apa yang telah dilakukan konseli pada waktu-waktu yang lalu untuk mengatasi stresnya.

Ketiga, mendoakan dan berdoa bersama konseli. Cara ini sangat menolong konseli agar hidupnya tetap terarah kepada Tuhan. Konselor dapat mengingatkan konseli beberapa ayat Firman Tuhan yang menguatkan dan memberi penghiburan. ${ }^{18}$

Keith W. Sehnert menjelaskan juga cara mengatasi stres, yaitu dengan memelihara tubuh dengan makan, beristirahat dan berolah raga yang baik. Stamina tubuh akan menjadi sehat dan kuat sehingga dapat bekerja dengan baik. Selain itu juga harus memenuhi kebutuhan rohani dengan berdoa, ibadah dan merenungkan Firman Tuhan. ${ }^{19}$ Pengasuh anak balita bisa menggunakan cara-cara ini sehingga stres yang dialaminya dapat diatas.

\section{KESIMPULAN}

Anak balita membutuhkan pengasuhan. Mereka sedang dalam masa tumbuh kembang. Pekerjaan sebagai pengasuh anak termasuk dalam pekerjaan yang rentan terhadap stres. Stres ini berdampak baik bagi anak maupun pengasuh itu sendiri. Stres ini perlu diatasi. Kehadiran konselor dapat menolong pengasuh anak mengatasi stres yang dialaminya.

Konseling stres kepada pengasuh anak balita adalah hubungan antara konselor dengan pengasuh anak balita, dimana konselor berusaha menolong konseli yang membutuhkan pengertian untuk mengatasi stress yang sedang dialaminya. Selama fase pembimbingan, seorang konselor akan menolong pengasuh anak balita mengatasi stres yang dialaminya.

\section{DAFTAR KEPUSTAKAAN}

Bornstein, Marc, H (Editor). Handbook Of Parenting Vol. 1. Children And Parenting. London: Lawrence Erlbaum Associates, 2002.

Collins, Gary, R. Konseling Kristen Yang Efektif. Malang: SAAT, 2012

Goliszek, Andrew.Manajemen Stres. Jakarta: Bhuana Ilmu Populer, 2005

\footnotetext{
${ }^{19}$ Keith W. Sehnert, M.D., 85-86
}

\footnotetext{
${ }^{17}$ Gary R. Collins, 64

${ }^{18}$ Gary Collins, 97
} 
Hardjana, Agus, M. Stres Tanpa Distres. Seni Mengolah Stres. Yogyakarta: Kanisius, 2002

Sehnert, Keith, W, M.D. Mengendalikan Stres Dalam Rumah Tangga Dan Pekerjaan. Bandung: Kalam Hidup, t.t

Setiadarma, Monty, P. "Mewaspadai Stres Pengasuh.", Dari Anak Sampai Usia Lanjut. Jakarta: BPK Gunung Mulia, 2004 